\title{
PENGEMBANGAN PERANGKAT PENILAIAN BERBASIS KELAS UNTUK PEMBELAJARAN KIMIA SEKOLAH MENENGAH ATAS POKOK BAHASAN STOIKIOMETRI
}

\author{
Betty Holiwarni*, Erviyenni \\ Program Studi Pendidikan Kimia FKIP Universitas Riau \\ E-mail: warniholy@gmail.com
}

\begin{abstract}
One of the causes that classroom-based assessment has not been applied in Senior High School nowadays because most of chemistry teachers have difficulties to develop the desired assessment as needed at the educational unit level curriculum. To solve this problem, a research was done to develop classroom-based assessment tool that is valid, practical, and effective for chemistry learning material in stoichiometry on Senior High School. The research method used was a development research. Research activities were conducted three years consisting of three stages, namely front-back analysis,prototyping, and implementation. Date were collected throught classroom observations, interviews with students, teachers, chemistry education expert,student work analysis, and achievement test. The result of first year showed that classroom-based assessment tool developed showed the validity criteria in term of its content and construction. The implementation conducted in the second year in SMAN 1 Pekanbaru, SMA Babussalam, and SMAN 2 Siak Hulu. The implementation result also showed the practical criteria, meaning that students and teachers can use it without significant constaint.
\end{abstract}

Key words: Classroom-Based Assessment Tool, Stoichiometry

\begin{abstract}
Abstrak
Salah satu faktor penyebab belum diterapkan penilaian berbasis kelas di sekolah-sekolah dewasa ini karena guru kimia mengalami kesulitan untuk merancang dan mengembangkan penilaian sesuai yang diinginkan kurikulum. Untuk memecahkan masalah ini, maka dilakukan penelitian untuk mengembangkan perangkat penilaian berbasis kelas yang valid, praktikal, dan efektif untuk pembelajaran kimia SMA pokok bahasan stoikiometri. Metode penelitian yang digunakan adalah development research. Penelitian dilaksanakan dalam tiga tahun dan terdiri dari tiga tahap, yaitu analisis muka belakang, prototipe, dan implementasi. Data penelitian dikumpulkan melalui observasi kelas, wawancara dengan siswa, guru, pakar pendidikan kimia, analisis hasil kerja siswa, dan tes. Hasil penelitian tahun pertama menunjukkan bahwa perangkat penilaian berbasis kelas yang dikembangkan memenuhi kriteria valid dari segi isi dan konstruksi. Ujicoba dilakukan pada tahun kedua penelitian di SMAN 1 Pekanbaru, SMA Babussalam, dan SMAN 2 Siak Hulu. Hasil Ujicoba juga memenuhi kriteria praktis, yang mana guru dan siswa dapat menggunakan perangkat penilaian berbasis kelas dalam pembelajaran kimia, tanpa kendala berarti.
\end{abstract}

Kata Kunci: Penilaian berbasis kelas, stoikiometri 


\section{PENDAHULUAN}

Salah satu perubahan mendasar yang terjadi dengan diterapkannya kurikulum berbasis kompetensi adalah perubahan penilaian pembelajaran. Selama ini, praktek penilaian pembelajaran yang dilakukan guru di kelas masih menekankan pada aspek kognitif, yang diukur melalui paper and pencil test. Penilaian tersebut lebih diarahkan pada penguasaan bahan yang diujikan dalam bentuk tes objektif dan kurang menggunakan cara dan alat penilaian yang bervariasi (Sukiman, 2012). Sementara, kurikulum mengisyaratkan untuk menerapkan penilaian berbasis kelas (penilaian autentik).

Permasalahan yang berkembang di sekolah-sekolah pada saat ini adalah pada umumnya guru kimia mengalami kesulitan untuk merancang, mengembangkan, dan menerapkan penilaian berbasis kelas seperti yang diharapkan oleh kurikulum berbasis kompetensi. Hasil penelitian pengembangan mutu pendidikan (PPMP) oleh Betty (2011), Evi (2011), Jimmi (2011), Yennita (2011) di beberapa Sekolah Menengah Atas di propinsi Riau ditemukan bahwa sebahagian besar guru kimia belum memahami tentang penilaian berbasis kelas, akibatnya penilaian yang dirancang oleh guru-guru kimia masih bersifat konvensional yaitu paper and pencil test.

Mengacu pada permasalahan-permasalahan yang terjadi di sekolah, serta belum tersedianya perangkat penilaian untuk pembelajaran kimia di Sekolah Menengah Atas, maka melalui penelitian ini dikembangkan perangkat penilaian berbasis kelas untuk pembelajaran kimia Sekolah Menengah Atas pokok bahasan stoikiometri. Hasil penelitian ini diharapkan dapat membantu guru kimia mengatasi kesulitan mereka dalam melaksanakan penilaian berbasis kelas.

Permasalahan yang ingin dipecahkan melalui penelitian ini adalah: bagaimana mengembangkan perangkat penilaian berbasis kelas yang valid, praktikal, dan efektif untuk pembelajaran kimia Sekolah Menengah Atas pokok bahasan stoikiometri? Istilah valid, praktikal dan efektif yang digunakan mengacu pada kriteria yang dikemukakan oleh Guskey (2000) dan Nieveen (1999).

Stoikiometri menyangkut cara (perhitungan kimia) untuk menghitung spesi kimia atau dengan kata lain, stoikiometri adalah kajian tentang hubungan-hubungan dalam reaksi kimia (Harjono, 2010). Stoikiometri adalah salah satu materi pokok yang dipelajari dalam mata pelajaran kimia di Sekolah Menengah Atas. Materi pelajaran dimulai dengan mempelajari hukum-hukum dasar, konsep mol, dan setelah itu baru masuk pada perhitungan kimia. Kompetensi dasar untuk pokok bahasan stoikiometri adalah membuktikan dan mengkomunikasikan berlakunya hukum-hukum dasar kimia melalui percobaan serta menerapkan konsep mol dalam menyelesaikan perhitungan kimia.

Penilaian adalah serangkaian kegiatan untuk memperoleh, menganalisis, dan menafsirkan data tentang proses dan hasil belajar siswa yang dilakukan secara sistematis dan 
berkesinambungan, sehingga menjadi informasi yang bermakna dalam mengambil keputusan (Depdiknas, 2004). Penilaian yang dilakukan secara komprehensif sepanjang proses pembelajaran disebut penilaian berbasis kelas (Sukiman, 2012).

Penilaian Berbasis Kelas pada hakekatnya merupakan suatu proses pengumpulan, pengolahan, pelaporan, dan penggunaan informasi tentang hasil belajar bagi peserta didik dengan menerapkan prinsip-prinsip penilaian, pelaksanaan berkelanjutan, bukti-bukti autentik, akurat dan konsisten sebagai akuntabilitas publik yang dilakukan terpadu dengan kegiatan belajar mengajar di kelas (Sukiman, 2012), dengan tujuan untuk mengungkap apa yang diketahui dan apa yang dapat dilakukan siswa, berbeda dengan penilaian pembelajaran konvensional yang hanya dapat mengungkap apa yang diketahui siswa. Melalui penilaian berbasis kelas guru tidak hanya mendapatkan gambaran tentang pemahaman siswa terhadap konsep-konsep yang telah mereka pelajari (Eko, 2009). Lebih dari itu, guru dapat mengungkap sikap dan motivasi siswa terhadap pelajaran serta kemampuan pemecahan masalah, penalaran, komunikasi, dan koneksi siswa (Muslimin, 2011). Penilaian berbasis kelas dapat dilakukan guru melalui berbagai teknik penilaian otentik diantaranya: kinerja, pertanyaan, proyek, jurnal, portofolio, investigasi, observasi, wawancara, konferensi, evaluasi diri oleh siswa, tes buatan siswa dan paper and pencil test (Nana, 2012).

Perangkat penilaian yang dikembangkan dalam penelitian ini menggunakan teknik-teknik seperti dikemukakan di atas. Untuk pokok bahasan stoikiometri perangkat penilaian yang dikembangkan dapat digunakan untuk mengakses pemahaman konsep, keterampilan melakukan praktek di laboratorium, kemampuan memecahkan masalah, keterampilan mempresentasikan hasil kerja, sikap dalam kerja kelompok, penilaian portofolio, penilaian diri, penilaian antar teman. Jenis penilaian yang digunakan pada masing-masing pokok bahasan disesuaikan dengan karakteristik materi.

\section{METODE PENELITIAN}

Penelitian ini dilaksanakan selama tiga tahun dengan menggunakan metode development research yang dikemukakan oleh Thiagarajan (1974). Kegiatan penelitian meliputi tiga tahap, analisis kebutuhan, merancang prototipe, dan implementasi. Penelitian pada tahun I difokuskan untuk merancang prototipe perangkat penilaian berbasis kelas yang valid untuk pembelajaran kimia di kelas X Sekolah Menengah Atas. Kegiatan penelitian diawali dengan analisis kebutuhan yang meliputi: analisis kurikulum kimia, melakukan wawancara dengan guru dan siswa, serta mereviuw literatur tentang penilaian dan perancangannya. Berdasarkan hasil analisis dirancang prototipe perangkat penilaian berbasis kelas. 
Prototipe perangkat penilaian berbasis kelas yang dikembangkan divalidasi oleh dua pakar pendidikan kimia dan satu orang pakar penilaian pembelajaran kimia. Kegiatan validasi dilakukan dalam bentuk tertulis dan diskusi sampai tercapai suatu kondisi yang mana para validator berpendapat bahwa perangkat penilaian yang dikembangkan sudah valid dan layak untuk digunakan di sekolah. Setelah proses validasi, dilakukan revisi terhadap prototipe perangkat penilaian berbasis kelas.

Pada tahun II, prototipe perangkat penilaian hasil revisi diujicobakan di tiga SMA, yaitu SMAN 1 Pekanbaru, SMA Babussalam, dan SMAN 2 Siak Hulu untuk melihat praktikalitas (keterpakaian) prototipe perangkat penilaian tersebut. Pemilihan variasi sekolah dimaksudkan untuk melihat keterpakaian perangkat penilaian berbasis kelas dengan kondisi sekolah yang berbeda. Data Penelitian sewaktu ujicoba dikumpulkan belalui observasi kelas, wawancara dengan guru dan siswa, serta analisis hasil kerja siswa. Data yang terkumpul dianalisis secara deskriptif.

Penelitian pada tahun III adalah untuk melihat efektivitas perangkat penilaian berbasis kelas terhadap pemahaman konsep, keterampilan melakukan praktek di laboratorium, kemampuan memecahkan masalah, keterampilan mempresentasikan hasil kerja, sikap dalam kerja kelompok, penilaian portofolio, penilaian diri, dan penilaian antar teman. Metode penelitian yang digunakan adalah penelitian tindakan kelas. Penelitian saat ini baru sampai tahap ujicoba untuk melihat praktikalitas perangkat penilaian berbasis kelas.

\section{HASIL PENELITIAN DAN PEMBAHASAN}

Pada bagian ini diuraikan hasil yang telah diperoleh berdasarkan kegiatan penelitian yang telah dilaksanakan. Hasil tersebut meliputi perangkat penilaian berbasis kelas yang telah dikembangkan untuk pokok bahasan stoikiometri dan hasil ujicoba di tiga SMA untuk melihat praktikalitas (keterpakaian) prototipe perangkat hasil revisi setelah dilakukan validasi.

\section{Perangkat penilaian berbasis kelas yang dikembangkan meliputi:}

Perangkat penilaian yang dikembangkan mencakup tiga kompetensi yakni, kompetensi pengetahuan, kompetensi sikap, dan kompetensi keterampilan.

a. Penilaian kompetensi pengetahuan adalah penilaian terhadap segala upaya yang menyangkut aktivitas otak yang berhubungan dengan kemampuan berpikir peserta didik yang meliputi memanggil kembali informasi dalam memori jangka panjang, mengingat, menerapkan, menganalisis, mengevaluasi, merancang, sampai kepada menciptakan sesuatu yang baru. Perangkat penilaian yang dikembangkan berupa tes tertulis dan lembar observasi saat diskusi, tanya jawab serta percakapan.

b. Penilaian kompetensi sikap adalah penilaian terhadap perasaan (suka atau tidak suka) terkait 
dengan kecenderungan seseorang dalam merespon sesuatu/objek. Sikap yang di nilai pada lembar penilaian ini adalah rasa ingin tahu, jujur, disiplin, tanggung jawab, kerjasama, dan komunikatif. Perangkat penilaian yang dikembangkan berupa lembar observasi penilaian sikap pada kegiatan praktikum dan pada saat diskusi, penilaian diri (menilai dirinya sendiri berkaitan dengan tingkat pencapaian kompetensi yang dipelajarinya), dan penilaian teman sebaya (peserta didik diminta untuk saling menilai terkait dengan pencapaian kompetensi).

c. Penilaian kompetensi keterampilan

Keterampilan berpikir siswa yang dinilai adalah keterampilan berpikir kritis seperti menganalisis, merumuskan masalah, mengumpulkan data, memecahkan masalah dan menilai. Perangkat penilaian yang dikembangkan untuk penilaian kompetensi keterampilan adalah lembar observasi unjuk kerja/praktik, lembar penilaian proyek, dan portofolio

\section{Ujicoba perangkat penilaian berbasis kelas}

Penilaian pengetahuan berupa tes tertulis, penilaian diri, dan penilaian antar teman diujicobakan pada siswa sedangkan lembar observasi penilaian unjuk kerja, penilaian sikap, penilaian proyek dan penilaian portofolio diujicobakan kepada guru.

a. Hasil ujicoba perangkat penilaian terhadap siswa

Hasil observasi kelas yang dilakukan selama ujicoba perangkat penilaian berbasis kelas dan hasil wawancara terhadap siswa di sekolah sampel, terlihat bahwa para siswa tidak mengalami kesulitan yang berarti atau para siswa dapat memahami setiap kalimat/kata yang tertulis pada setiap item pertanyaan/ pernyataan yang ada pada masing-masing lembar penilaian. Untuk penilaian diri dan penilaian antar teman sebelum kegiatan dimulai, guru memberikan penjelasan tentang apa tujuan dan manfaat dari penilaian tersebut terutama untuk SMAN 2 Siak Hulu karena kedua jenis penilaian tersebut bagi siswa adalah sesuatu yang baru dan belum pernah dilakukan, tetapi untuk SMAN 1 Pekanbaru dan terutama untuk SMA Babussalam tidak perlu penjelasan lebih rinci sebab penilaian seperti ini sudah biasa dilakukan meskipun versinya berbeda tetapi tujuannya sama. SMA Babussalam siswa tinggal di asrama, setiap periode tertentu pimpinan asrama meminta laporan tentang aktivitas tertentu yang dilakukan teman yang mereka nilai.

Pada penilaian pengetahuan berupa tes tertulis, keterpakaian (praktikalitas) perangkat penilaian dapat dilihat dari hasil kerja siswa dalam menjawab soal-soal yang ada pada lembar penilaian, di samping hasil penilaian observasi kelas selama ujicoba dan hasil wawancara dengan siswa setelah pelaksanaan kegiatan. Berdasarkan penilaian terhadap hasil kerja siswa dalam menjawab soal, kesalahan yang terjadi karena mereka memang belum/kurang memahami konsep-konsep pada materi yang sedang dipelajari sehingga banyak siswa yang tidak dapat 
menjawab dengan baik dan benar soal-soal pada lembar penilaian bukan karena kesalahan dalam memahami soal-soal yang ada.

b. Hasil ujicoba perangkat penilaian terhadap guru

Hasil observasi kelas yang dilakukan selama ujicoba perangkat penilaian berbasis kelas dan hasil wawancara dengan guru ditiga sekolah sampel, terlihat bahwa guru tidak mengalami kesulitan yang berarti atau guru dapat memahami setiap kalimat/kata yang tertulis pada setiap item pernyataan yang ada pada masing-masing lembar penilaian, permasalahan yang muncul adalah pada teknis pelaksanaan setiap kegiatan.

i. Penilaian sikap pada kegiatan diskusi kelompok

Pada saat diskusi kelompok terutama pada SMAN 2 Siak Hulu, banyak siswa yang bermainmain dan kurang serius belajar karena kegiatan diskusi kelompok kooperatif dalam pembelajan jarang dilakukan. Hal ini disebabkan karena ruangan kelas terlalu kecil untuk jumlah siswa yang besar, sehingga merubah posisi tempat duduk tidak mudah selalu menimbulkan keributan dan kegaduhan. Berbeda dengan SMAN 1 Pekanbaru dan SMA Babussalam dimana jumlah siswa tidak terlalu banyak dan siswa sudah terbiasa belajar kelompok baik kelompok dengan tatanan kooperatif maupun kelompok konvensional.

ii. Penilaian sikap dan pengetahuan pada saat presentasi

Dalam mempresentasikan hasil kerja siswa di depan kelas, untuk SMAN 1 Pekanbaru dan SMA Babussalam tidak ada masalah, mereka berlomba-lomba ingin tampil mempresentasikan hasil kerja kelompok mereka tetapi berbeda dengan SMAN 2 Siak Hulu, umumnya siswa masih malu-malu/ragu-ragu untuk maju ke depan kelas, bahkan ada siswa yang diam/tidak bisa bicara setelah berdiri dimuka teman-temannya yang mentertawakan mereka sehingga guru perlu motivasi siswa untuk membangkitkan kepercayaan diri mereka. Hal ini disebabkan karena kegiatan seperti ini tidak pernah dilakukan dalam pembelajaran. Berbeda dengan SMAN 1 Pekanbaru dan SMA Babussalam dimana kegiatan pembelajaran seperti ini sudah sering dilakukan karena pembelajaran sudah berpusat kepada siswa.

iii. Penilaian portofolio

Untuk pokok bahasan stoikiometri, setiap pertemuan siswa diminta membuat ringkasan materi yang akan dipelajari di rumah berdasarkan buku pegangan yang ada pada siswa dan dikumpulkan waktu pembelajaran akan dimulai. Penilaian dilakukan terhadap perkembangan kemampuan siswa membuat ringkasan. Dari hasil penilaian terhadap kerja siswa, diketahui bahwa banyak siswa yang belum dapat membuat ringkasan dengan baik dan benar, banyak siswa hanya menyalin keseluruhan isi buku atau menyalin sebahagian dari isi buku. Untuk memecahkan masalah ini guru harus mengajarkan kepada siswa bagaimana cara membuat ringkasan yang baik dan benar. 
Seperti diuraikan sebelumnya, penilaian berbasis kelas bertujuan untuk mengungkap apa yang diketahui dan apa yang dapat dilakukan siswa. Melalui penilaian berbasis kelas, siswasiswa di SMAN 1 Pekanbaru, SMA Babussalam, dan SMAN 2 Siak Hulu telah mendapat kesempatan untuk menunjukkan potensi mereka dalam kemampuan memahami dan menerapkan konsep, serta menunjukkan potensi mereka dalam kerja kelompok, berkomunikasi, bernalar berargumentasi dan sebagainya sesuai dengan tuntutan kurikulum. Hal seperti ini tidak mereka temui dalam paper and pencil tes yang cenderung hanya mengukur aspek kognitif yang dangkal. Di samping itu, dalam penilaian berbasis kelas, siswa berkompetisi dengan diri mereka sendiri sehingga dapat memacu anak dalam belajar (Depdiknas, 2004).

\section{KESIMPULAN}

Berdasarkan pembahasan yang telah dikemukakan di atas dapat disimpulkan bahwa perangkat penilaian berbasis kelas yang dikembangkan untuk pembelajaran kimia kelas X SMA pokok bahasan stoikiometri:

1. Memenuhi kriteria valid dari segi isi dan konstruksi.

2. Perangkat penilaian berbasis kelas dapat digunakan oleh guru dan siswa sesuai dengan kriteria yang diharapkan (praktis digunakan).

\section{UCAPAN TERIMA KASIH}

Peneliti mengucapkan terimakasih kepada DP2M DIKTI yang telah mendanai program ini melalui skim penelitian Hibah Bersaing dan Lembaga Penelitian dan Pengabdian Kepada Masyarakat Universitas Riau Pekanbaru yang telah mensupport penelitian ini.

\section{DAFTAR PUSTAKA}

Betty, H., 2011, Pemetaan dan Pengembangan Mutu Pendidikan di Kota Dumai dan Kabupaten Rokan Hilir Propinsi Riau, Laporan Penelitian tidak dipublikasikan.

Depdiknas., 2004., Pedoman Umum Penilaian, Puskur Balitbang, Jakarta

Eko, P. W., 2009, Evaluasi Program Pembelajaran: Panduan Praktis Bagi Pendidik dan Calon Pendidik, Pustaka Pelajar, Yogyakarta

Evi, S., 2011, Analisis Kompetensi Siswa SMA pada mata pelajaran Ujian Nasional untuk Pemetaan dan Pengembangan Mutu Pendidikan di Kabupaten Bengkalis dan Kepulauan Meranti Propinsi Riau. Laporan Penelitian tidak dipublikasikan.

Guskey, T.R., 1999, New Perspectives on Evaluating Profesional Development, Paper Presented at AERA Annual Meeting, Montreal, Canada, April 1999

Guskey, T.R., 2000, Evaluating Profesional Development, Thousand Oaks: SAGE. 
Hardjono, S., 2010. Kimia Dasar, Gadjah Mada University Press, Yogyakarta

Jimmi, C., 2011, Pemetaan dan Pengembangan Mutu Pendidikan di Kota Pekanbaru, Kabupaten Pelalawan, dan Kabupaten Siak Propinsi Riau, Laporan Penelitian tidak dipublikasikan

Mulyasa, H.E., 2014, Pengembangan dan Implementasi Kurikulum 2013, Remaja Rosdakarya, Bandung

Muslimin, I., 2011, Integrasi Fenomena IPA dalam Pembelajaran : Sebuah Alternatif Pendidikan Komprehensif, Bunga Rampai Pendidikan Karakter Strategi Mendidik Generasi Masa Depan, University Press, Surabaya

Nana, S., 2012. Penilaian Hasil Proses Belajar Mengajar, Remaja Rosdakarya, Bandung:

Nieveen, N.M., 1999. Prototyping to Reach Product Quality. In J. vanden Akker, R, Branch, K. Gustafson, N. Nieveen and Tj. Plomp (Eds). Design and development Methodology in Education. Dodrecht, The Netherlands: Kluwer Academic Publisher.

Sukiman., 2012., Pengembangan Sistem Evaluasi, Insan Madani, Yokyakarta

Thiagarajan., Semmel., Semmel., 1974, Instrucsional Development for Training Teachers of Exceptional Children. A Source Book, Blomington Center of Inovasion on Teaching the Handicapped. Minneapolis Indiana University.

Yennita, R., 2011, Pemetaan dan Pengembangan Mutu Pendidikan di Kabupaten Kampar, dan Kabupaten Rokan Hulu Propinsi Riau, Laporan Penelitian tidak dipublikasikan 